\title{
Direct and indirect effects of cob traits on yield in exotic maize germplasm under nitrogen deficient conditions
}

Tauseef Taj Kiani ${ }^{1}$, Waqas Ahmad ${ }^{1 *}$, Mozammil Hussain ${ }^{1}$, Tahir Amir Khan $^{2}$, Rizwana Amber ${ }^{1}$, Uzma Kalsoom ${ }^{1}$ and Azhar Hussain ${ }^{1}$

1. Maize, Sorghum, Millet and Fodder Program, Crop Sciences Institute, National Agricultural Research Centre, Islamabad-Pakistan

2. Crop Sciences Research Directorate, Balochistan Agricultural Research and Development Centre, Quetta, Balochistan-Pakistan

*Corresponding author's email: waqas.9066@yahoo.com

Citation

Tauseef Taj Kiani, Waqas Ahmad, Mozammil Hussain, Tahir Amir Khan, Rizwana Amber, Uzma Kalsoom and Azhar Hussain. Direct and indirect effects of cob traits on yield in exotic maize germplasm under nitrogen deficient conditions. Pure and Applied Biology. Vol. 6, Issue 4, pp1088-1095. http://dx.doi.org/10.19045/bspab.2017.600116

\begin{tabular}{llll}
\hline Received: 12/04/2017 & Revised: 26/08/2017 & Accepted: 05/09/2017 & Online First: 09/09/2017 \\
\hline
\end{tabular}

\section{Abstract}

Despite of adoption of hybrid maize cultivation to a considerable level, maize yields in Pakistan are lower than other countries in the region. With others, maize cultivation under low soil fertility and without supplemental nitrogenous inputs is an important reason for low yields. This derives national maize breeding programs to develop low-nitrogen responsive maize cultivars. In this context, exotic maize open-pollinated varieties were introduced from CIMMYT for adaptability testing and subsequent adaptation. The trial including these OPVs was planted under zero nitrogen application. Correlation and path coefficient analysis was used to establish association of grain yield with its components to ascertain specific selection criteria which will be used to enhance efficiency of the future maize breeding and yield improvement programs using this germplasm. The results complemented with heritability estimates revealed that 100kernel weight and shelling percentage together with kernel rows per cob can be utilized effectively for yield enhancement under nitrogen deficient conditions.

Keywords: Correlation; Low nitrogen; Maize; Path analysis; Yield

\section{Introduction}

Maize varies from other cereals in a number of aspects like having open pollination, expression of heterosis and multifarious uses such as; the grain can be eaten as human food, fermented to produce a wide range of food beverages and used as an industrial input in the production of starch, oil, sugar, protein, cellulose and ethyl alcohol [1]. After wheat and rice, maize is third most produced cereal of Pakistan. Its production and per hectare yield took an upsurge starting in mid-90s then rising sharply in early 2000s and onwards (Figure 1 and 2). The introduction and adaptation of hybrid maize with production technology can be attributed as a main reason for this gain. However, maize yield in Pakistan is comparatively low as compared to the global average as well as in comparison with the countries in the region like China, Bangladesh, Vietnam and Iran (Figure 2). 
The reason of low yields in Pakistan is less area under hybrid cultivation i.e around only 39-41 percent of total area under maize. The main hindrance in promotion of hybrid cultivation is un-affordability of world-ever high prices of maize hybrid seed. Moreover, the fact of owing predominantly temperate genetics from US corn-belt also provides limitation in promotion and adaptation of hybrid cultivation due to vulnerability of temperate material to blights in wet monsoons. In addition, high input cost such as nitrogenous fertilizers also acts as a restrictive factor preventing the adaptation of hybrid maize by small farmers who constitute a considerable faction of maize growers in Pakistan and they continue to grow open-pollinated varieties with lesser inputs. This situation is not much different from other tropical developing countries where cultivation is usually done under low nitrogen availability, consequent of low natural soil fertility and low investment in nitrogenous fertilizers [2].

To address the needs of these farmers, many open-pollinated varieties have been developed and released in the country by National Agriculture Research System (NARS) such as Sarhad white, Sarhad Yellow, Kashmir Gold, Azam, Kissan, Jalal, Ageti-2002 and some indigenous hybrids like Fakhr-e-NARC, Babar, Karamat, Yousafwala Hybrid and FHY 810. The cooperation of the Centro Internacional de Mejoramiento de Maiz y Trigo (CIMMYT) has always been there in acquisition of germplasm, transfer of technology and making efforts jointly with public-private stakeholders towards uplifting the socio- economic conditions of small farmers. In a similar collaboration, low-nitrogen responsive germplasm have been given to Pakistan for testing and subsequent adaptation in different agro-ecological regions of Pakistan. These open-pollinated varieties are intended to become integral part of indigenous maize breeding programs to ignite breeding schemes aiming to develop low nitrogen tolerant open pollinated varieties or derive inbred lines for hybrid development.

Selection criteria are pre-requisite for any crop improvement and yield has been the prime target of maize breeding and improvement initiatives. Grain yield is complex trait, quantitative in nature and have low heritability which greatly influenced by environmental factors. Solely, it can't serve as an efficient and effective selection criterion for yield improvement programs. However, selection based on knowledge of yield contributing traits would be fruitful. While correlation coefficient helps to establish the association between traits, path coefficient analysis allows partitioning of correlation coefficients into direct and indirect contributions of various traits towards specific character [3].

Knowledge of such cause and effect relationship between yield and its component in context of specific environment such as drought or low nitrogen also improves efficiency of selection program targeted for yield improvement. This present study will help to establish association between different yield related traits. 


\section{Maize production in Pakistan}

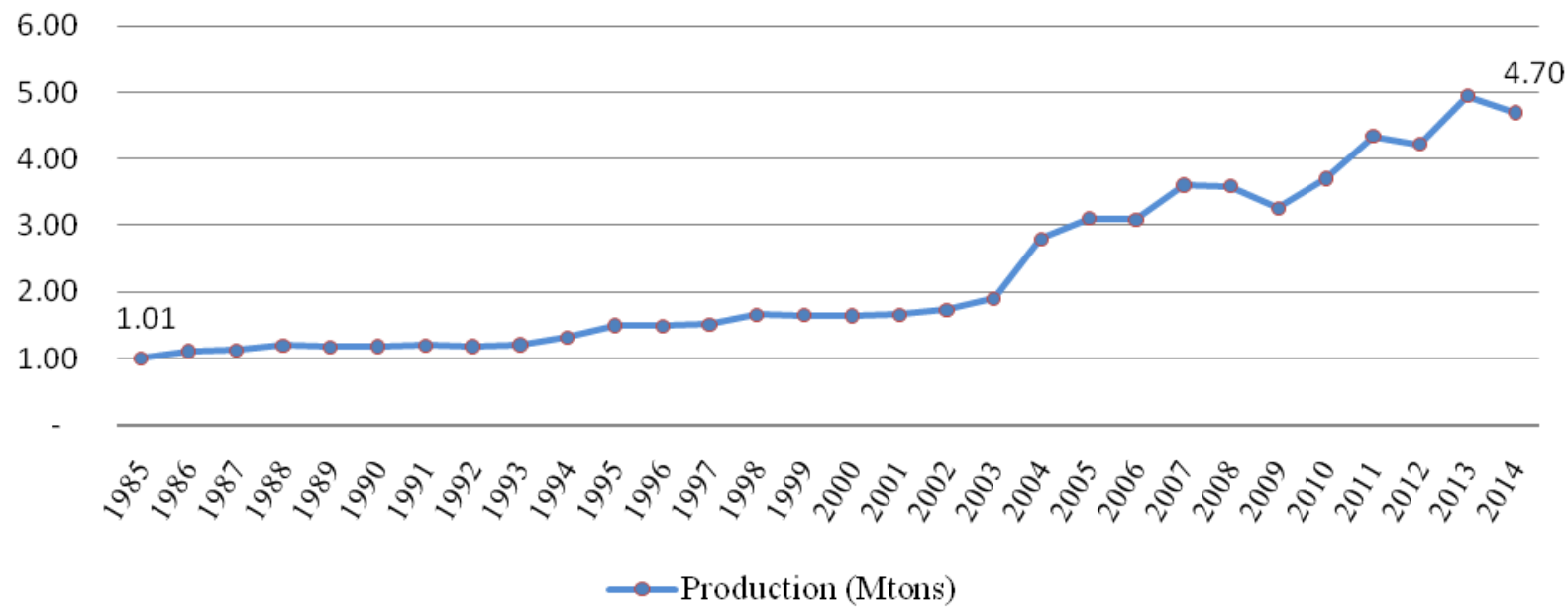

Figure 1. Maize production in Pakistan from 1985 to 2014 (http://faostat3.fao.org/)

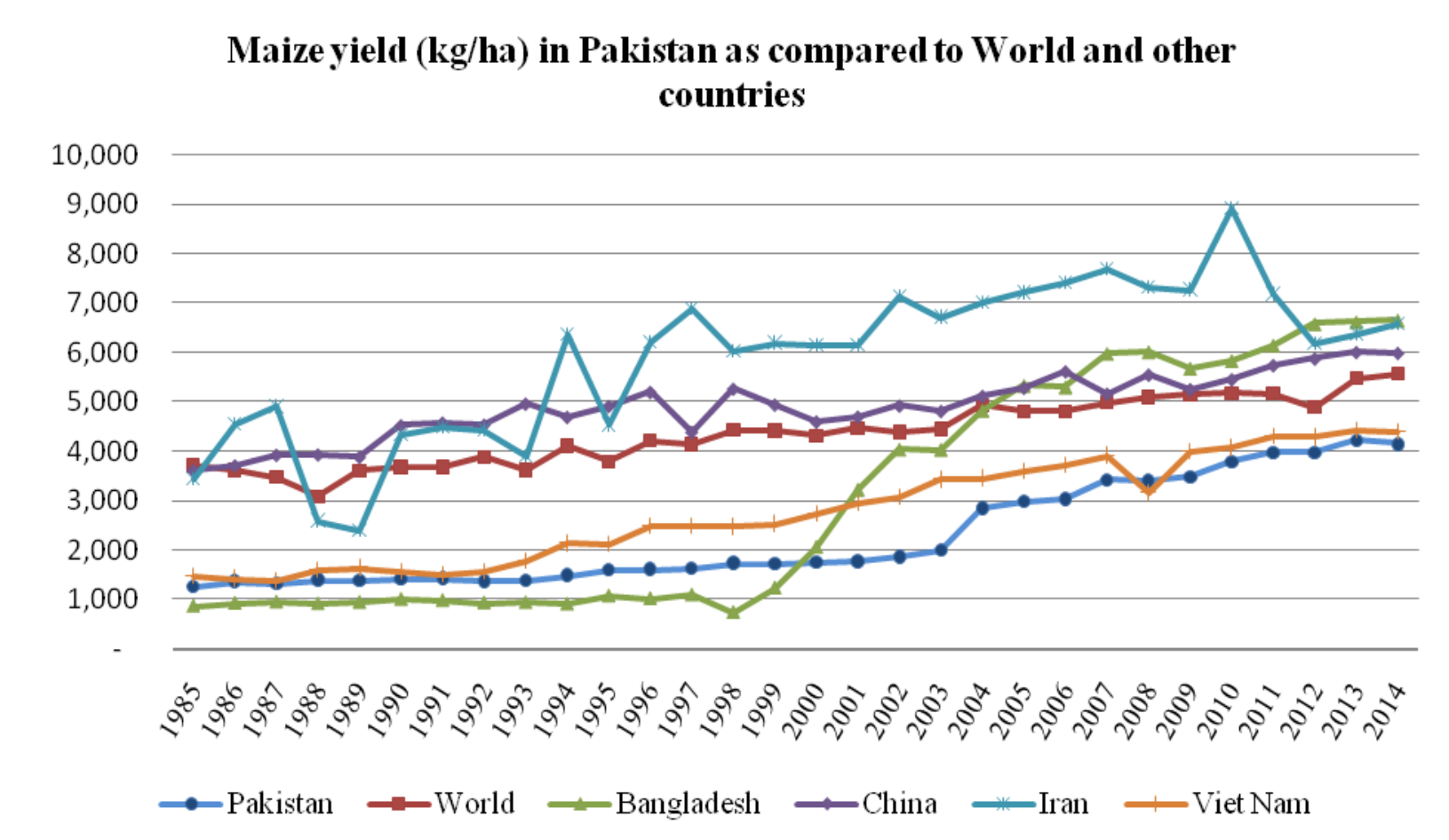

Figure 2. Maize yields of World, Pakistan, Bangladesh, China, Iran and Viet Nam (http://faostat3.fao.org/) 


\section{Material and methods}

The present study comprised of ten exotic low-nitrogen responsive open pollinated varieties introduced from CIMMYT and two local checks. These genotypes were planted in replicated alpha lattice design having three replications containing two-row plots for each entry. The trial was maintained following all recommended agronomic practices except for fertilizer application. The nitrogen, phosphate and potash were applied at the rate of 0:150:100 kg per acre. The study was conducted in Maize, Millet,
Sorghum and Fodder Program's research field at National Agricultural Research Centre Islamabad during kharif 2015. Five plants of each entry were selected randomly for data collection. Data on yield parameters like 100-kernel weight, kernel rows per cob, kernels per row, shelling percentage, cob length, cob girth and grain yield were recorded. Fresh cob and grain weights were used to determine shelling percentage which was then used to compute grain yield (tons per hectare) at constant moisture (15\%) by using the formula :-

Grain yield $=\frac{\text { Fresh cob weight }(100-\text { observed moisture }) \times \text { shelling } \% \times 10,000}{85 \times \text { plot area } \times 1000}$

Data was analyzed by analysis of variance according to Steel and Torrie [4]. The observed variances were partitioned into genotypic $\left(\sigma^{2} \mathrm{~g}\right)$, phenotypic $\left(\sigma_{\mathrm{p}}^{2}\right)$ and environmental $\left(\sigma_{\mathrm{e}}^{2}\right)$ components. Using these components, broad sense heritability was worked out using the formula:

Heritability (broad sense) $=\frac{\sigma_{g}^{2}}{\sigma_{p}^{2}}$ (Singh and Chaudhary [5]).

The genotypic components of variance for different traits were used to calculate correlation coefficients. Path coefficient analysis was done by solving following equations by matrix method as elaborate by Singh and Chaudhary [5]:

$$
\begin{aligned}
& r_{1.7}=\mathrm{P}_{1.7}+\mathrm{r}_{1.2} \mathrm{P}_{2.7}+\mathrm{r}_{1.3} \mathrm{P}_{3.7}+\mathrm{r}_{1.4} \mathrm{P}_{4.7}+ \\
& \mathrm{r}_{1.5} \mathrm{P}_{5.7}+\mathrm{r}_{1.6} \mathrm{P}_{6.7} \\
& \mathrm{r}_{2.7}=\mathrm{r}_{1.2} \mathrm{P}_{1.7}+\mathrm{P}_{2.7}+\mathrm{r}_{2.3} \mathrm{P}_{3.7}+\mathrm{r}_{2.4} \mathrm{P}_{4.7}+ \\
& \mathrm{r}_{2.5} \mathrm{P}_{5.7}+\mathrm{r}_{2.6} \mathrm{P}_{6.7} \\
& \mathrm{r}_{3.7}=\mathrm{r}_{1.3} \mathrm{P}_{1.7}+\mathrm{r}_{2.3} \mathrm{P}_{2.7}+\mathrm{P}_{3.7}+\mathrm{r}_{3.4} \mathrm{P}_{4.7}+ \\
& \mathrm{r}_{3.5} \mathrm{P}_{5.7}+\mathrm{r}_{3.6} \mathrm{P}_{6.7} \\
& \mathrm{r}_{4.7}=\mathrm{r}_{1.4} \mathrm{P}_{1.7}+\mathrm{r}_{2.4} \mathrm{P}_{2.7}+\mathrm{r}_{3.4} \mathrm{P}_{3.7}+\mathrm{P}_{4.7}+ \\
& \mathrm{r}_{4.5} \mathrm{P}_{5.7}+\mathrm{r}_{4.6} \mathrm{P}_{6.7} \\
& \mathrm{r}_{5.7}=\mathrm{r}_{1.5} \mathrm{P}_{1.7}+\mathrm{r}_{2.5} \mathrm{P}_{2.7}+\mathrm{r}_{3.5} \mathrm{P}_{3.7}+\mathrm{r}_{4.5} \mathrm{P}_{4.7}+ \\
& \mathrm{P}_{5.7}+\mathrm{r}_{5.6} \mathrm{P}_{6.7} \\
& \mathrm{r}_{6.7}=\mathrm{r}_{1.6} \mathrm{P}_{1.7}+\mathrm{r}_{2.6} \mathrm{P}_{2.7}+\mathrm{r}_{3.6} \mathrm{P}_{3.7}+\mathrm{r}_{4.6} \mathrm{P}_{4.7}+ \\
& \mathrm{r}_{5.6} \mathrm{P}_{5.7}+\mathrm{P}_{6.7} \text { where } \mathrm{r}_{1.2}, \mathrm{r}_{1.3} \text { and so on are } \\
& \text { correlation coefficients and } \mathrm{P}_{1.7}, \mathrm{P}_{2.7} \text { and so } \\
& \text { on are direct effects of yield components. }
\end{aligned}
$$

\section{Results}

The results of analysis of variance established significant difference among genotypes for all the traits under study except for cob length (Table 1). Results of correlation coefficient are given in Table 2. It was observed that 100-kerneal weight had significant negative correlation with number of kernel rows per cob and cob length. However, highly significant positive correlations of this trait were observed with shelling percentage $(0.87)$, cob girth $(0.57)$ and grain yield (0.89). However number of kernel rows displayed insignificant correlation with grain yield and significant positive correlation was noted between cob girth and number of kernel rows i.e 0.45 . Kernels per row also demonstrated nonsignificant positive correlation with either yield or its components. On contrary, shelling percentage was observed to be highly significantly correlated with cob length (0.43) and grain yield (0.70). Interestingly, cob length was also found to be negatively correlated with cob girth and grain yield as opposed to cob girth which was significantly positively correlated with grain yield (0.66).

The results of path coefficient analysis are presented in Table 3. Traits like 100-kernel 
weight (0.924), number of kernel rows per cob (1.825), kernels per row (0.235) and shelling percentage (1.303) demonstrated positive direct effects to grain yield. On the other hand, cob length (-0.306) and cob girth $(-0.711)$ both showed negative direct effects towards grain yield. For all traits, the indirect effects through other yield contributing attributes were a mix of both positives and negatives. For instance, number of kernel rows per cob having highest positive direct effect had negative indirect effects through all other traits. Whereas, cob girth showing negative direct effects demonstrated positive indirect effects through 100-kernel weight (0.529), kernel rows per cob (0.817), shelling percentage (0.040) and cob length (0.051).

Table 1. Analysis of variance for grain yield and other cob traits

\begin{tabular}{|c|c|c|c|c|c|c|c|c|}
\hline & & Mean squar & values & & & & & \\
\hline $\begin{array}{l}\text { Source of } \\
\text { variance }\end{array}$ & d.f & $\begin{array}{l}\text { 100-kernel } \\
\text { weight }\end{array}$ & $\begin{array}{l}\text { No. of kernel } \\
\text { rows/cob }\end{array}$ & $\begin{array}{l}\text { No. of } \\
\text { kernels/row }\end{array}$ & $\begin{array}{l}\text { Shelling } \\
\%\end{array}$ & $\begin{array}{l}\text { Cob } \\
\text { length }\end{array}$ & $\begin{array}{l}\text { Cob } \\
\text { girth }\end{array}$ & $\begin{array}{l}\text { Grain } \\
\text { yield }\end{array}$ \\
\hline Replications & 3 & $44.93 * *$ & 0.27 & 4.410 & $165.26 * *$ & $3.97^{*}$ & 0.06 & 1.69 \\
\hline Genotypes & 11 & $25.82 * *$ & $7.07 * *$ & $15.28 *$ & $115.70^{* *} *$ & 1.70 & $0.25 * *$ & $3.49 * *$ \\
\hline Error & 33 & 7.53 & 0.86 & 6.87 & 31.95 & 1.13 & 0.03 & 1.04 \\
\hline
\end{tabular}

* Significant at $5 \%$ probability, $* *$ significant at $1 \%$ probability

Table 2. Genotypic correlation coefficients between yield and its components

\begin{tabular}{|l|l|l|l|l|l|l|l|}
\hline Traits & $\begin{array}{l}100-\text { kernel } \\
\text { weight }\end{array}$ & $\begin{array}{l}\text { No. of kernel } \\
\text { rows/cob }\end{array}$ & $\begin{array}{l}\text { No. of } \\
\text { kernels/row }\end{array}$ & $\begin{array}{l}\text { Shelling } \\
\%\end{array}$ & $\begin{array}{l}\text { Cob } \\
\text { length }\end{array}$ & $\begin{array}{l}\text { Cob } \\
\text { girth }\end{array}$ & $\begin{array}{l}\text { Grain } \\
\text { yield }\end{array}$ \\
\hline 100-kernel weight & 1.00 & & & & & & \\
\hline Kernel rows/cob & $-0.50^{* *}$ & 1.00 & & & & & \\
\hline Kernels/row & $-0.09 \mathrm{~ns}$ & $-0.31^{* *}$ & 1.00 & & & & \\
\hline Shelling \% & $0.87^{* *}$ & $-0.69^{* *}$ & $0.01 \mathrm{~ns}$ & 1.00 & & & \\
\hline Cob length & $-0.60^{* *}$ & $0.04 \mathrm{~ns}$ & $-0.30^{* *}$ & $0.43^{* *}$ & 1.00 & & \\
\hline Cob girth & $0.57^{* *}$ & $0.45^{* *}$ & $-0.33^{* *}$ & $0.03 \mathrm{~ns}$ & $-0.19^{*}$ & 1.00 & \\
\hline Grain yield & $0.89^{* *}$ & $0.06 \mathrm{~ns}$ & $-0.06 \mathrm{~ns}$ & $0.70^{* *}$ & $-0.17^{*}$ & $0.66^{* *}$ & 1.00 \\
\hline
\end{tabular}

* Significant at $1 \%$ probability, ** Significant at $0.1 \%$ probability, ns non-significant

Table 3. Direct (diagonal) and indirect effects of yield components towards grain yield and heritability estimates

\begin{tabular}{|l|l|l|l|l|l|l|l|}
\hline Traits & $\begin{array}{l}100- \\
\text { kernel } \\
\text { weight }\end{array}$ & $\begin{array}{l}\text { No. of } \\
\text { kernel } \\
\text { rows/cob }\end{array}$ & $\begin{array}{l}\text { No. of } \\
\text { kernels/row }\end{array}$ & $\begin{array}{l}\text { Shelling } \\
\%\end{array}$ & $\begin{array}{l}\text { Cob } \\
\text { length }\end{array}$ & $\begin{array}{l}\text { Cob } \\
\text { girth }\end{array}$ & Heritability \\
\hline 100-kernel weight & 0.924 & -0.921 & -0.021 & 1.137 & 0.182 & -0.407 & 0.378 \\
\hline Kernel rows/cob & -0.467 & 1.825 & -0.072 & -0.895 & -0.011 & -0.318 & 0.644 \\
\hline Kernels/row & -0.081 & -0.557 & 0.235 & 0.012 & 0.093 & 0.234 & 0.234 \\
\hline Shelling \% & 0.807 & -1.253 & 0.002 & 1.303 & -0.132 & -0.022 & 0.396 \\
\hline Cob length & -0.551 & 0.065 & -0.072 & 0.561 & -0.306 & 0.136 & 0.114 \\
\hline Cob girth & 0.529 & 0.817 & -0.077 & 0.040 & 0.051 & -0.711 & 0.696 \\
\hline \multicolumn{7}{|c|}{ Residual effects: 0.88} \\
\hline
\end{tabular}

\section{Discussion}

Environmental stresses like water scarcity, temperature hikes low soil fertility pose a great challenge to the maize productions especially in developing countries. Maize breeders and associated scientists are constantly working to counter these challenges and develop high-yielding well 
adapted maize varieties and hybrids. However, to develop an effective and productive selection program; the basic step of any crop improvement program, development of selection criteria becomes vital. This increases the selection efficiency and yield improvement under target environments. The utilization of correlation coefficients in formulating a fruitful breeding strategy has long been applied in maize. However, yield is a complex quantitative trait which expresses variably under different environments and the expression is contributed by many other yield components. Under such circumstances, simple correlation between yield and its components doesn't serve the purpose. Therefore, path analysis can be used to develop more reliable selection criteria which elaborate both direct and indirect effects of different morphophysiological components towards grain yield. Even in recent years, many studies have been reported the exploitation of this technique in maize [6-11].

In the similar context, the present study was conducted to establish correlations between yield and its components complemented with heritability estimates in exotic lownitrogen responsive maize germplasm. Path analysis was used to dissect the correlations into direct and indirect effects. These analyses were done when analysis of variance established significant differences among genotypes for most of the traits studied. The correlation between 100-kernel weight and grain yield was significantly positive and its direct effects were also positive towards yield. Rahman et al. [12], Kumar et al. [13] and Hefny [14] also reported positive direct effects for yield component as opposed to Moradi and Azarpour [15] who observed minute role of 1000-grain weight towards grain yield. Moreover, the values for correlation and direct effects of 100-kernel weight in this study were almost equal indicating a true relationship between this trait and grain yield. Therefore, direct selection for 100kernel weight can be effective in improving grain yield under low-nitrogen conditions. Although, number of kernel rows per cob had a considerable positive direct effects towards yield, but the correlation between these two traits remained insignificant. This could be due to negative indirect effects of all other studied traits through kernel rows per cob. High heritability (64.4\%) and its positive direct effects makes a case for utilization of kernel rows per cob for yield improvement but in a restricted selection model so that restrictions are imposed to avoid negative indirect effects of other yield attributes as suggested by Singh and Chaudhary [5]. Positive significant direct effects of kernel rows per cob have also been reported by Sreckov et al. [16], and Rafiq et al. [17]. When it came to number of kernels per row, negative correlation with grain yield was observed contrary to positive direct effects of smaller magnitude. This might have occurred due to positive indirect effects through cob girth, cob length and shelling percentage. Shelling percentage however, not only demonstrated significant positive correlation but positive direct effects also. The magnitude of direct effects was mainly enhanced due to positive indirect effects through 100-kernel weight. Both traits were also strongly positively correlated; selection through them for yield improvement under low-nitrogen circumstances would be fruitful. This significant role of shelling percentage in enhancing grain yield was in contrast to the study of Ojo et al. [18] who reported its role to be least important among other traits.

Interestingly, cob length and cob girth both demonstrated negative direct effects in contradiction of Ilker [9] who reported significant positive contribution of cob length. Cob length was negatively correlated 
with grain yield. However, cob girth was significantly positively correlated mainly due to positive indirect effects through traits like 100-kernel weight, kernel rows/cob and shelling percentage. These positive indirect effects of cob girth through these attributes complemented with its positive correlations and considerably high heritability estimates $(69.6 \%)$ points towards usefulness of cob girth as selection criterion in combination with 100-kernel weight, kernel rows/cob and shelling percentage. Despite of all this information, the residual effects $(88 \%)$ showed that the trait under study accounted $22 \%$ variability in the yield. This might be due to insignificant or negative correlations of kernel rows per cob, kernels per row and cob length. This also suggests role of other morpho-physiological factors playing role in yield which were not included in this study.

\section{Authors' contributions}

Conceived and designed the experiments:

W Ahmad, TT Kiani \& M Hussain, Performed the Experiments: W Ahmad, TA Khan \& TT Kiani, Analyzed the Data: TA Khan, W Ahmad \& R Amber, Contributed reagents/ materials/ analysis tools: R Amber, U Kalsoom \& A Hussain, Wrote the paper: TT Kiani, W Ahmad \& M Hussain.

\section{Acknowledgements}

The authors are thankful to Abdurrahman Bashir of CIMMYT Pakistan for providing the germplasm under AIP-project; Muhammad Ashraf and Salman Saleem of MSM\& F program, National Agriculture Research Centre, Islamabad for planting and maintenance of above trial.

\section{References}

1. Morris ML (2002). Impacts of international maize breeding research in developing countries, 1966-98. CIMMYT. D.F, Mexico.

2. Monneveux P, Zaidi PH \& Sanches C (2005). Population density and low nitrogen affect yield-associated traits in tropical maize. Crop Sci 45: 535 - 545.
3. Adesoji AG, Abubakar IU \& Labe DA (2015). Character association and path coefficient analysis of maize (Zea mays L.) grown under incorporated legume and nitrogen. J Agro 14(3): 158 - 163.

4. Steel RGD \& Torrie JH (1984). Principles and procedures of statistics (2nd Ed.). MC Graw Hill Book Co; Singapore, pp. 172-177.

5. Singh RK \& Chaudhary BD (2004). Biometrical methods in quantitative genetics analysis. New Delhi, India.

6. Pavlov J, Delic N, Markovic K, Crevar M, Camdzija Z \& Stevanovic M (2015). Path analysis for morphological traits in maize (Zea mays L.). Genetika 47(1): $295-301$.

7. Zarei B, Kahrizi D, Aboughadareh AP \& Sadeghi F (2012). Correlation and path coefficient analysis for determining interrelationships among grain yield and related characters in corn hybrids (Zea mays L.). Intern J Agric Crop Sci 4(20): 1519-1522.

8. Collado MB, Arturi MJ, Aulicino MB \& Molina MC (2011). Use of foliage and root characters for the evaluation of salinity tolerance at seedling stage in maize. Revista de la Facultad de Agronomia La Plata 110(1): 12 - 19.

9. Ilker E (2011). Correlation and path coefficient analyses in sweet corn. Turk J Field Crops 16(2): 105 - 107.

10. Sreckov Z, Nastasic A, Bocanski J, Djalovic I, Vukosavljev M \& Jockovic B (2011). Correlation and path analysis of grain yield and morphological traits in test-cross populations of maize. Pak J Bot 43(3): 1729 - 1731.

11. Bello OB, Abdulmaliq SY, Afolabi MS \& Ige SA (2010). Correlation and path coefficient analysis of yield and agronomic characters among open pollinated maize varieties and their $F_{1}$ hybrids in a di-allele cross. African $J$ Biotech 9(18): 2633 - 2639. 
12. Rahman MW, Talukder MAI, Mamun MAA, Hanif MA \& Uddin MJ (2015). Studies on genetic variability, correlation and path analysis of yield attribute in maize genotypes (Zea mays L.). J Chem Biol Phy Sci 5(4): 3964 3971.

13. Kumar V, Singh SK, Bhati PK, Sharma A, Sharma SK \& Mahajan V (2014). Correlation, path and genetic diversity analysis in maize (Zea mays L.). Environ \& Eco 33(2a): 971 - 975.

14. Hefny M (2011). Genetic parameters and path analysis of yield and its components in corn inbred lines (Zea mays L.) at different sowing dates. Asian J Crop Sci 3(3): $106-117$.

15. Moradi M \& Azarpour E (2011). Determination of most important part of yield components by path analysis in corn. J American Sci 7(5): 646 - 650.

16. Sreckov Z, Bocanski J, Nastasic A, Dalovic I \& Vukosavljev M (2010). Correlation and path coefficient analysis of morphological traits of maize ( $\mathrm{Zea}$ mays L.). Res J Agric Sci 42(2): 292 296.

17. Rafiq CM, Rafique M, Hussain A \& Altaf M (2010). Studies on heritability, correlation and path analysis in maize (Zea mays L.). J Agri Res 48(1): 35 - 38.

18. Ojo DK, Omikunle OA, Oduwaye OA, Ajala MO \& Ogunbayo SA (2006). Heritability, character correlation and path coefficient analysis among six inbred-lines of maize (Zea mays L.). World J Agri Sci 2(3): 352 - 358. 